\title{
ELEKTRONICKÝ OBCHOD A OCHRANA OSOBNÝCH ÚDAJOV
}

\author{
Viera Šukalová*, Pavel Ceniga*
}

Úvod

Informačné a komunikačné technológie významne ovplyvňujú moderný život spoločnosti. Dostávajú sa postupne do všetkých sfér l'udských aktivít, či už pracovných alebo súkromných, obchod nevynímajúc. Moderné trendy v obchodovaní prinášajú vel'a výhod, ale majú aj svoje bariéry a riziká. Na manažérov v oblasti elektronického obchodu sú kladené špecifické požiadavky; medzi ne patrí aj osobitná znalost' povinností v súvislosti s ochranou osobných údajov svojich zákazníkov. Článok sa zaoberá analýzou súčasného stavu v tejto oblasti i analýzou právnych znalostí ako súčasti kompetencií moderného manažéra elektronického obchodu. Príspevok je parciálnym výstupom výskumu v oblasti stanovenia kompetenčného modelu manažéra elektronického obchodu, ktorý nie je v súčasnosti v dostupnej literatúre popísaný, ale stanovenie ktorého je nevyhnutné z hl'adiska moderného kompetenčného prístupu v riadení podnikov. Kompetenčný model obsahuje jednotlivé kompetencie, popisuje konkrétnu kombináciu vedomostí, schopností a d'alších charakteristík osobnosti, ktoré sú potrebné k efektívnemu plneniu úloh podniku. Slúži na rýchlu a jasnú orientáciu v tom, akých l'udí organizácia potrebuje, aké vlastnosti, schopnosti a zručnosti sú pre ňu typické a žiaduce. Je to usmernenie, v ktorých oblastiach treba zamestnancov rozvíjat'. Súvisí s konkrétnou pozíciou, konkrétnym podnikom a konkrétnym typom činnosti podniku.

\section{Elektronický obchod - moderná forma obchodovania}

Elektronický obchod využíva možnosti výpočtovej techniky a moderných komunikačných médií na účel vybavovania obchodných transakcií prostredníctvom internetu bez nutnosti fyzickej prítomnosti zúčastnených na transakcii. Ide teda o realizáciu obchodných procesov, ktoré sú uskutočňované celkom alebo čiastočne prostredníctvom elektronickej komunikácie, najmä prostredníctvom internetu.

Internet poskytuje pre elektronický obchod:

- siet' pre globálnu komunikáciu užívatel'ov,

- prostredie zabezpečujúce celý rad rôznych komunikačných služieb,

- prostriedok pre prístup k informáciám,

- prostredie pre vytváranie rôznych aplikácií (predaj, marketing),

- prostredie pre vytvorenie globálneho elektronického trhu.

\footnotetext{
*Ing. Viera Šukalová, EUR ING, PhD., ŽU v Žiline, F pEDAS, KE, Univerzitná 1, 01026 Žilina, tel.: +421415133214, e-mail: sukalova@fpedas.uniza.sk

* doc. Ing. Pavel Ceniga, PhD., ŽU v Žiline, F pEDAS, KE, Univerzitná 1, 01026 Žilina, tel.: +42141513328, e-mail: pavel.ceniga@fpedas.uniza.sk
} 
Z hl'adiska obchodnej transakcie predstavuje internet najmä marketingové propagačné médium, ktoré je charakteristické najmä:

- interaktivitou (možnost'ou okamžitej spätnej väzby od zákazníka),

- možnost'ou personifikácie (customizácia - prispôsobenie informácií alebo produktu požiadavkám zákazníka),

- špecifickým distribučným kanálom.

Hlavnou výhodou elektronického obchodu je komfortná forma nákupu, nízke režijné náklady, predajné systémy, ktoré sú k dispozícii 24 hodín a geograficky neobmedzená dostupnost'. Naopak, medzi nevýhody patrí nižšia dôvera zákazníkov ku kvalite takýchto transakcií. Problémom bývajú aj niektoré právne aspekty elektronického obchodovania a informačná bezpečnost'.

\section{Právne aspekty elektronického obchodu}

Elektronický obchod sa riadi najmä týmito zákonmi:

- Občiansky zákonník,

- Obchodný zákonník,

- Zákon o ochrane spotrebitel'a,

- Zákon o ochrane spotrebitel'a pri podomovom predaji a zásielkovom predaji,

- Zákon o elektronickom obchode,

- Zákon o ochrane osobných údajov.

Štátny dohl'ad nad elektronickým obchodom vykonáva Slovenská obchodná inšpekcia, ktorá kontroluje všetky aspekty prevádzkovania elektronického obchodu - kvalitu výrobkov, cenové otázky i podmienky skladovania či dopravy.

Základným dokumentom, ktorým sa riadi prevádzkovatel' elektronického obchodu sú obchodné podmienky. Sú súčast'ou kúpnej zmluvy a obsahujú základné práva a povinnosti zmluvných strán, teda prevádzkovatel'a elektronického obchodu a spotrebitel'a.

Tomuto dokumentu je potrebné venovat' náležitú pozornost' vzhl'adom na špecifiká tejto formy obchodovania. Uvedené predpisy riešia aj otázky ochrany informácií. [5,6,7]

\section{Informačná bezpečnost’ a elektronický obchod}

Informačná bezpečnost' má multilaterálny charakter, to znamená, že musí zohl'adňovat' záujmy vlastníkov informačných komunikačných systémov, ich užívatel'ov i práva fyzických a právnických osôb, ktorých údaje sa v systémoch spracovávajú. Z hl'adiska používatel'ov sú pri spracovaní informácie najdôležitejšie tieto faktory: účel a obsah informácií, presnost', aktuálnost', prístupnost', autenticita, usporiadanie a kvalita informácií. Z hl'adiska vlastníkov a prevádzkovatel'ov je najdôležitejší spol'ahlivý prístup k informačným zdrojom s prístupom on-line a ich zabezpečenie pred únikom informácií, neoprávneným použitím a narušením integrity údajov, ako aj autorita a dobré meno vlastníka systému.

Informačná bezpečnost' má význam aj pre elektronický obchod; únik alebo neoprávnená manipulácia s údajmi môže vážne poškodit' prevádzkovatel'a i spotrebitel'a. Informačná bezpečnost' je celosvetovým spoločenským problémom. V dôsledku nutnosti zabezpečit' informačnú bezpečnost' bol zavedený pojem „kybernetický zločin“, na základe Dohovoru o kybernetickom zločine CETS č. 185/2001 vydaného Radou Európy, ktorý je zapracovaný aj do nášho trestného zákonníka.

Kritickým faktorom pre zabezpečenie informačnej bezpečnosti je kompetentnost' l'udí, ktorá sa dosiahne len neustálym nadobúdaním a obnovovaním vedomostí v tejto oblasti či už 
v rámci štúdia alebo celoživotného vzdelávania. Nedostatok vedomostí často zapríčiňuje porušenie ochrany osobných údajov. [1,3]

\section{Stav ochrany osobných údajov v súčasnej podnikovej praxi}

Ochrana osobných údajov nie je novou témou, ale žial' doposial' často zanedbávanou z hl'adiska dôsledného plnenia povinností zodpovedných osôb za legálne manipulovanie s osobnými údajmi. Ochrana osobných údajov je zaručená Ústavou SR i osobitným zákonom, napriek tomu je možné predpokladat', že v praxi sa zákonné ustanovenia nedodržujú. Vzhl'adom na nedostatočné právne vedomie verejnosti v tejto oblasti i nedostatočné vzdelanie prevádzkovatel'ov elektronického obchodu, sú zákazníci vystavení viacerým rizikám vyplývajúcim z nesprávneho spracovania osobných údajov. Podla Správy o stave ochrany osobných údajov za roky 2009 až 2010 sa síce konštatuje, že 56\% občanov pozná svoje práva v oblasti ochrany osobných údajov, to však zd'aleka nemusí zodpovedat' reálnemu stavu. $\mathrm{Na}$ Úrad na ochranu osobných údajov sa so svojimi st’ažnost'ami obracajú len l’udia, ktorí poznajú svoje práva, na druhej strane si mnoho občanov ani neuvedomuje, že sú ich osobné údaje zneužívané.

V prípade elektronického obchodu sa vyžaduje poskytovanie osobných údajov na účel zmluvného vzt’ahu medzi predávajúcim a kupujúcim. V roku 2010 Úrad na ochranu osobných údajov vybral na kontrolu $\mathrm{z}$ radov internetových predajcov šestnást' prevádzkovatel'ov $\mathrm{v}$ jedenástich mestách v SR tak, aby boli zastúpené všetky slovenské kraje. Kontroly sa uskutočnili u prevádzkovatel'ov v Bratislave, Komárne, Košiciach, Prešove, Rožňave, Trnave, Nitre, Žiari nad Hronom, Banskej Bystrici, Martine a v Bojniciach.

Ciel'om híbkových kontrol bolo preverenie dodržiavania ustanovení zákona o ochrane osobných údajov s dôrazom na vedenie evidencie, rozsah získavaných a spracúvaných osobných údajov $\mathrm{v}$ jednotlivých informačných systémoch prevádzkovatel'ov vzhl'adom $\mathrm{k}$ účelu ich spracúvania, poskytovanie informácií dotknutým osobám pri získavaní ich osobných údajov o všetkých okolnostiach spracúvania ich osobných údajov, bezpečnost' a ochrana osobných údajov, písomné poverenie zodpovednej osoby, ak mal prevádzkovatel' viac ako pät' zamestnancov.

Výkonom dozornej činnosti sa zistilo, že 90 percent prevádzkovatel'ov nezamestnáva taký počet fyzických osôb, aby mohli poverit' zodpovednú osobu výkonom dohl'adu nad ochranou osobných údajov.

K najčastejším pochybeniam pri spracúvaní osobných údajov prevádzkovatel'mi z radov internetových predajcov dochádzalo pri uplatňovaní ustanovenia, podl'a ktorého je prevádzkovatel' povinný pri získavaní osobných údajov dotknutú osobu vopred a bez vyzvania informovat' o všetkých okolnostiach spracúvania jej osobných údajov, ktoré sú pre dotknutú osobu potrebné s ohl'adom na zaručenie jej práv a právom chránených záujmov, najmä právo byt' informovaná o podmienkach spracúvania jej osobných údajov. Výkonom dozoru u vybraných internetových predajcov sa zistilo, že prevádzkovatelia na svojich internetových stránkach, resp. v obchodných podmienkach uverejnených na týchto stránkach, dostatočne alebo vôbec neinformovali dotknuté osoby o všetkých okolnostiach spracúvania ich osobných údajov. Často tu absentovala informácia o tom, že osobné údaje $\mathrm{v}$ mene prevádzkovatel'a spracúva sprostredkovatel' a úplne chýbala informácia o právach dotknutej osoby.

Prevádzkovatelia porušovali zákon o ochrane osobných údajov aj tým, že získavali osobné údaje na účel plnenia kúpno-predajnej zmluvy, ktoré zároveň používali aj na marketingové účely. $\mathrm{K}$ porušovaniu dochádzalo tak, že záujemca o nákup tovaru sa musel najskôr zaregistrovat' a až potom mohol prehliadat' ponuku tovaru a príp. si ho objednat', pričom osobné údaje poskytnuté na účel registrácie sa využívali na marketingové účely. Dotknutá osoba v niektorých prípadoch síce mohla zakliknút'/nezakliknút' súhlas s používaním osobných údajov na marketing, ale bez súhlasu sa $\mathrm{v}$ mnohých prípadoch nedalo zaregistrovat' a bez registrácie tovar objednat'. V niektorých prípadoch bol tento súhlas na web stránke prevádzkovatel’a už zakliknutý vopred. [11] 
V každom prípade je oblast' elektronického obchodu ako moderná forma obchodovania $\mathrm{v}$ tomto smere riziková a preto je potrebné venovat' jej pozornost'. Vytvorenie kompetenčného modelu manažéra elektronického obchodu je jednou z ciest ako skvalitnit' jeho služby. Kompetenčný model súži v modernom podniku ako nástroj riadenia l'udských zdrojov, vo vzdelávacích inštitúciách ako základ tvorby učebných osnov a tréningových osnov. Pre tvorbu kompetenčného modelu je potrebné analyzovat' aj požiadavky na právne znalosti, okrem iného i v oblasti ochrany osobných údajov.

Je to pomerne nová kompetencia, podobne ako inteligenčné kompetencie (IQ), ktoré predstavujú širokú škálu schopností vecného, odborného a metodického charakteru, schopnosti analytického a systémového myslenia, ako aj špecifické schopnosti a zručnosti (napríklad zvládnutie práce s novými médiami a internetom).

\section{Ochrana osobných údajov}

Každý prevádzkovatel' elektronického obchodu spravuje databázu osobných údajov svojich zákazníkov. Ochrana osobných údajov sa v dnešnej dobe stáva neoddelitel'nou súčast'ou života celej modernej spoločnosti. Je považovaná za základné l'udské právo, jej dôležitost' a význam podčiarkuje Európska únia tým, že začlenila ochranu osobných údajov do Charty základných práv EÚ. Závažnost' problematiky ochrany osobných údajov dokumentuje aj skutočnost', že porušenie práva na ochranu osobných údajov sa považuje za trestný čin. Podmienky spracovania osobných údajov upravuje zákon o ochrane osobných údajov.

Narastajúci záujem kompetentných inštitúcií i právnických a fyzických osôb o problematiku ochrany osobných údajov je pochopitel'ný. Nie je pravdepodobné, že by časom došlo v tejto oblasti ku zjednodušeniu situácie. Ochrana osobných údajov určite nie je problémom, ktorý postupne vymizne práve naopak, oprávnene sa dá predpokladat' nárast problémov a komplikácií v tejto oblasti a preto je potrebné venovat' jej trvalú pozornost'.

Osobnými údajmi sú údaje týkajúce sa určenej alebo určitel'nej fyzickej osoby, pričom takou osobou je osoba, ktorú možno určit' priamo alebo nepriamo, najmä na základe všeobecne použitel'ného identifikátora alebo na základe jednej či viacerých charakteristík alebo znakov, ktoré tvoria jej fyzickú, fyziologickú, psychickú, mentálnu, ekonomickú, kultúrnu alebo sociálnu identitu. [4]

V zákone nie sú taxatívne vymenované údaje, ktoré sú považované za osobné. Pri posudzovaní, či sa jedná alebo nejedná o osobné údaje, je totiž nutné brat' do úvahy všetky okolnosti týkajúce sa daných údajov. Najdôležitejšou charakteristikou osobných údajov je odpoved' na otázku, či je možné podl'a daných údajov priamo určit' osobu, ktorej sa týkajú. Ak je zverejnené iba meno a priezvisko - nie je to osobný údaj, lebo v našom geografickom priestore je viacero osôb, ktoré môžu mat' rovnaké meno a priezvisko. Ani rodné číslo samo o sebe nie je osobný údaj - z rodného čísla vieme určit' dátum narodenia a pohlavie, nevieme určit konkrétnu osobu, ktorej toto rodné číslo patrí.. Napr. rodné číslo a adresu už možno považovat' za osobný údaj, lebo podl'a týchto dvoch charakteristík sa dá jednoznačne určit', identifikovat' osoba. Výnimočne sa teda jedná o jeden údaj, na základe, ktorého je osoba jednoznačne určitel'ná, napríklad tvár na fotografii, väčšinou sa však jedná o súbor údajov. Osobné údaje možno rozdelit' na tieto kategórie:

- identifikačné údaje, medzi ktoré patria najmä meno, priezvisko, titul, rodné číslo, rodinný stav, štátne občianstvo, zamestnanie a vzdelanie,

- adresné údaje, medzi ktoré patria najmä adresa trvalého a prechodného pobytu, telefónne číslo, adresa elektronickej pošty, 
- popisné údaje, ktoré dopíňajú komplexný obraz fyzickej osoby, ako napr. údaje o pôvode, záujmoch, priebehu zamestnaní a pod.

- biometrické údaje, čo sú osobné údaje, na základe, ktorých je možné jednoznačne určit’ fyzickú osobu, ako napríklad odtlačok prsta, odtlačok dlane, analýza DNA, tvar tváre, hlas a pod.,

- anonymizované údaje, čo sú osobné údaje upravené do takej formy, že ich nemožno priradit' konkrétnej osobe,

- citlivé údaje, resp. osobitné kategórie osobných údajov, ktoré odhal'ujú rasový lebo etnický pôvod, politické názory, náboženskú vieru alebo svetonázor, členstvo v politických stranách alebo politických hnutiach, členstvo v odborových organizáciách, údaje týkajúce sa zdravia a pohlavného života - spracúvanie týchto údajov je v zmysle zákona o ochrane osobných údajov zakázané. [5]

Rodné číslo ako všeobecne použitel'ný identifikátor je v slovenskom prostredí špecifickým, široko diskutovaným, $\mathrm{z}$ mnohých dôvodov kontroverzným, ale stále ešte najčastejšie používaným identifikátorom. Je to osobní údaj výnimočný tím, že je „zámerne jedinečným identifikátorom, ktorý človek počas svojho života nemení“. [2]

\section{Spracovanie osobných údajov}

Spracovaním osobných údajov sa podl'a zákona o ochrane osobných údajov rozumie „vykonávanie akýchkol'vek operácií alebo súboru operácií s osobnými údajmi, napr. ich získavanie, zhromažd'ovanie, zaznamenávanie, usporadúvanie, prepracúvanie alebo zmena, vyhl'adávanie, prehliadanie, preskupovanie, kombinovanie, premiestňovanie, využívanie, uchovávanie, likvidácia, ich prenos, poskytovanie, sprístupňovanie alebo zverejňovanie“. Ked’že tento pojem je $\mathrm{v}$ zákone vymedzený vel'mi široko, využívanie osobných údajov napr. na účely priameho marketingu je potrebné považovat' za spracúvanie osobných údajov so všetkými dôsledkami.

Osobné údaje sa môžu spracúvat' len na základe súhlasu dotknutej osoby. Súhlas sa preukazuje zvukovým alebo zvukovo-obrazovým záznamom alebo čestným vyhlásením toho, kto poskytol osobné údaje do informačného systému, prípadne iným hodnoverným spôsobom. Za iný hodnoverný spôsob sa považuje napríklad elektronický dokument podpísaný zaručeným elektronickým podpisom. Dôkaz o súhlase musí obsahovat':

- údaj o tom, kto súhlas poskytol,

- komu sa tento súhlas dáva,

- na aký účel,

- zoznam alebo rozsah osobných údajov,

- dobu platnosti súhlasu a

- podmienky jeho odvolania.

Tento výpočet však nie je konečný, pokial' majú byt' údaje sprístupňované, zverejňované alebo poskytované, je potrebné uviest' v súhlase i tieto skutočnosti.

Súhlas v písomnej forme musí obsahovat' vlastnoručný podpis toho, kto osobné údaje poskytuje. (Súhlas sa nevyžaduje, ak sa osobné údaje spracúvajú na základe osobitného zákona; takýmto osobitným zákonom je napríklad zákon o sociálnom poistení alebo zákon o dani z príjmov.)

Pri získavaní osobných údajov od dotknutej osoby je na základe zákona oprávnená osoba povinná sa identifikovat' a bez vyzvania oznámit' dotknutej osobe nasledovné informácie:

- názov a sídlo prevádzkovatel'a, prípadne sprostredkovatel'a,

- účel spracúvania osobných údajov (určený zákonom alebo vymedzený prevádzkovatel'om),

- dobrovol'nost' alebo povinnost' poskytovat' požadované osobné údaje, 
- okruh užívatel'ov, ktorým budú osobné údaje sprístupnené (stačí vymedzit' okruh užívatel'ov určitel'ným spôsobom, nemusí byt' taxatívny),

- Všetky osoby vrátane subjektov v zahraničí, ktorým budú osobné údaje poskytnuté (ich zoznam je nutné uviest' taxatívne, za súčasného právneho stavu nepostačuje $\mathrm{v}$ tomto prípade určenie okruhu takýchto osôb),

- formu zverejnenia, ak majú byt' osobné údaje zverejnené,

- krajiny cezhraničného toku osobných údajov,

- poučenie o existencii práv dotknutej osoby.

Získavat' je možné osobné údaje len na presne vopred vymedzený účel.

Sprístupnenie osobných údajov znamená oznámenie osobných údajov alebo umožnenie prístupu $\mathrm{k}$ nim inej osobe $\mathrm{s}$ výnimkou dotknutej osoby, prevádzkovatel'a, sprostredkovatel'a alebo oprávnenej osoby. Osoby, ktorým sú osobné údaje len sprístupnené, nemôžu tieto osobné údaje spracúvat'.

Poskytnutie osobných údajov znamená odovzdávanie osobných údajov na spracúvanie inej osobe s výnimkou dotknutej osoby, prevádzkovatel'a, sprostredkovatel'a alebo oprávnenej osoby. Osoby, ktorým sú osobné údaje poskytnuté, ich môžu spracúvat'.

\section{Zodpovednost' za bezpečnost' osobných údajov}

Za bezpečnost' je zodpovedný prevádzkovatel' a sprostredkovatel', ktorí majú zo zákona povinnost' chránit' osobné údaje pred náhodným ako aj nezákonným poškodením a zničením, stratou, zmenou, nedovoleným prístupom a sprístupnením ako aj pred akýmikol'vek d'alšími nedovolenými formami spracovania. Táto povinnost' sa vzt'ahuje na všetky informačné systémy, v ktorých sa spracúvajú osobné údaje. Na tento účel prijímajú primerané technické, personálne a organizačné opatrenia, v závislosti na spôsobe spracovania.

\section{Záver}

Koncepcia ochrany osobných údajov nemá dlhú tradíciu hoci osobné údaje existujú od pradávna. Problémom ich ochrany sa začala venovat' pozornost' až s vývojom moderných demokratických zriadení. Potreba legislatívneho vymedzenia ochrany osobných údajov sa stala naliehavejšou v súvislosti $\mathrm{s}$ vývojom automatizovaných systémov na ich spracovanie. Porušenie zásad ochrany osobných údajov pri prevádzke elektronického obchodu napriek existencii presných pravidiel stále predstavuje vážne riziko a preto je nevyhnutné tejto problematike venovat' trvalú pozornost'. Komplexne stanovený kompetenčný model pre manažéra v oblasti elektronického obchodu a jeho efektívne využitie vo vzdelávaní i riadení l'udských zdrojov je moderným riešením pre teóriu i prax.

Príspevokje výstupom riešenia projektu: 2/KE/2012 Analýza právnych znalosti v práci manažéra a ich aplikácia $v$ manažmente podniku.

\section{Literatúra}

[1] MORAVČÍKOVÁ, A.: Ochrana osobných údajov v informačných systémoch. IN: Justičná revue, č.52, 2000, č.12, s.1293-1300

[2] SCHELLE, K., ŠMíD,V.: Rodné číslo v informačních systémech. IN: Právní rádce: Měsíčník hospodářských novin, Praha: ECONOMIA, roč.12, 2004, č.11, s.44-47, ISSN 1210-4817 
[3] ŠMíD, V.: Právní režim informačních systémů obsahujícících osobní údaje.IN: Celostátní konference Tvorba softwaru 2003. Sborník př́spěvků. Ostrava : TANGER s.r.o. 2003, s 196-206, ISBN 80-85988-84-6

[4] ŠUKALOVÁ, V.: Manažment ochrany osobných údajov v podnikovej praxi. In: Globalizácia a jej sociálno-ekonomické dôsledky '09 : elektronický zborník príspevkov z medzinárodnej vedeckej konferencie : 29. 9. - 1.10. 2009 Rajecké Teplice, Slovenská republika. - ISSN 1336-5878. - Žilina: Žilinská univerzita, 2009. S. 504-509

[5] Zákon č. 428/2002 Z.z. o ochrane osobných údajov

[6] Zákon č. 610/2003 Z.z. o elektronických komunikáciách

[7] Zákon č. 22/2004 Z.z. o elektronickom obchode.

[8] Zákon č.40/1964 Zb. Občiansky zákonník v znení neskorších predpisov

[9] Zákon č. 513/1991 Zb. Obchodný zákonník

[10] ŠUKALOVÁ a kol.: 2/KE/2012 Analýza právnych znalosti v práci manažéra a ich aplikácia v manažmente podniku, projekt inštitucionálneho výskumu, ŽU v Žiline, F PEDAS

[11]http://www.dataprotection.gov.sk/buxus/docs/Sprava_o_stave_ochrany_osobnych_udajov _2009-2010. 